\title{
ABDULLAH BIN ABBAS DAN PERANNYA DALAM PENAFSIRAN AL-QUR'AN: Studi Tafsir Abdullah bin Abbas dalam Nuskhah Ali Bin Abi Tholhah
}

\author{
Mohammad Izdiyan Muttaqin \\ moh.izdiyan@uinjkat.ac.id
}

\begin{abstract}
Abstrak
Artikel ini mendiskusikan tentang Abdullah bin Abbas dan peranannya dalam penafsiran al-Qur'an. Penulis juga membahas ciri-ciri penafsiran Abdullah bin Abbas yang diriwayatkan dalam nuskhah Ali bin Abi Tholhah. Artikel ini menjelaskan riwayat hidup Abdullah bin Abbas, dan konsistensinya dalam menghimpun hadits dan Ilmu-ilmu al-Qur'an, sehingga ia dijuluki sebagai Turjuman al-Qur'an. Penulis juga memberikan penjelasan tentang pentingnya nuskhah Ali bin Abi Tholhah, sebagai salah satu teks terbaik yang menghimpun tafsir Abdullah bin Abbas. Secara umum tafsir Abdullah bin Abbas mencakup sebagian ayat dari 106 surat dalam al-Qur'an, dan ada 8 surat yang tidak ditafsirkan oleh Ibnu Abbas. Hal ini diyakini karena ayat-ayat tersebut sudah bisa dipahami oleh Umat Islam pada masa itu. Tafsir Ibnu Abbas secara umum menggunakan tiga metode utama: tafsir al-Qur'an dengan al-Qur'an, tafsir al-Qur'an dengan as-Sunnah, dan tafsir al-Qur'an dengan lisan Bangsa Arab. Tafsir Ibnu Abbas juga mencakup berbagai cabang ilmu al-Qur'an, seperti Makki-Madani, Nasikh-Mansukh, Asbab Nuzul, Hukum-hukum Fiqih, Penjelasan kisah-kisah al-Qur'an, dan penjelasan perumpamaan-perumpamaan dalam al-Qur'an.
\end{abstract}

Kata Kunci : Tafsir, Abdullah bin Abbas, Ali bin Abi Tholhah

\begin{abstract}
This article dicusses the role of Abdullah bin Abbas in intepreting Qur'an. The author also talked about the methods of interpretetion according to Abdullah bin Abbas, which is found in the nuskhah (text) transmitted by Ali bin Abi Thalhah. This nuskhah is considered as the best way of the transmition of Ibnu Abbas's Interpretation of Qur'an. This article tells some biography of Abdullah bin Abbas one of the Prophet's Desciple, which was known as "The Translator of Qur'an". The author also explained the importance of nuskhah Ali bin Abi Thalhah, as the best text containing the interpretation of Abdullah bin Abbas. The interpretation of Abdullah bin Abbas consists of some verses of about 106 surah, there are 8 surah which were not interpreted by Ibnu Abbas. Maybe because those surah can be understood easily bu Muslims at that time. Generally Ibnu Abbas used three mind methods: interpretation of qur'an using qur'an, interpretation of qur'an using hadits of the Prophet, and interpretation of Qur'an using knowledge of Arabic Language. Ibnu Abbas also explained about many important majors in his interpretation, such as: Makki Madani, Nasikh-Mansukh, Asbab Nuzul, Fiqh, Explanations of Qur'anic Stories, and Explanations of examples in Qur'an.
\end{abstract}

Keywords: Interpretation, Abdullah bin Abbas, Ali bin Abi Tholhah 


\section{A. Pendahuluan}

Al-Qur'an merupakan kitab suci yang menjadi magnet bagi Umat Manusia di seluruh Dunia. Dalam kajian keislaman sendiri, al-Qur'an merupakan teks paling suci di antara semua teks yang ada, ia lebih mulia daripada hadits Nabi Muhammad Saw dan juga hadits qudsi ${ }^{1}$. Al-Qur'an sedikitnya memiliki empat keistimewaan dibandingkan teks-teks lain dalam kajian keislaman. Pertama, Umat Islam mengimani bahwa ia murni dari Sang Pencipta, baik dalam segi lafaz maupun maknanya ${ }^{2}$. Kedua, ia diturunkan untuk seluruh alam, bukan hanya untuk kaum tertentu, sebagaimana Nabi-Nabi sebelum Nabi Muhammad ${ }^{3}$. Ketiga, al-Qur'an merupakan teks yang mengandung nilai ibadah jika dibaca ${ }^{4}$. Keempat, al-Qur'an diriwayatkan secara mutawatir dari generasi ke generasi ${ }^{5}$. Begitu kuatnya periwayatan al-Qur'an, sehingga setiap ayatnya diriwayatkan oleh orang banyak orang. Al-Qur'an dijaga oleh Umat Islam baik secara audio dalam bentuk hafalan maupun tulisan dalam bentuk teks dari generasi ke generasi. Bukan hanya ditulis, al-Qur'an juga dibaca dan dihafalkan dengan suara yang indah ${ }^{6}$. Perubahan satu huruf pun, akan mengundang banyak pertanyaan dari para penghafal dan pengkaji al-Qur'an di seluruh Dunia.

1 Khalil Manna' Al-Qattan, Mabahits fi Ulum al-Qur'an (Islamic Books, 2000), 30.

2 Muhammad Rofah, "Musahamah Ulama al-Maghrib al-Ausath alHadhoriyah Min Khilal Tafsir as-Syaikh Hud Bin Muhkam al-Hawari”, atTa'limiyah. 6(1), 2018, 163-174.

3 A. Munir, "Konsep Dasar Pendidikan Dalam al-Qur'an", Kreatif: Jurnal Studi Pemikiran Pendidikan Agama Islam, 13(2), 2015, 110-120.

${ }^{4}$ M. Z. Arifin, Handayani, D., Phantawi, S., \& Nipapan, N. Studi "Living Qur'an: Pembacaan Ayat-Ayat al-Qur'an dalam Prosesi Isi Qubur di Kota Bangkok Thailand”, Realita, 14(1), 2016.

5 I. M. Sobki, Yusof, N., \& Yusof, Y, "Qira'at Reading as-Sunnah Muttaba'ah: A Perspective Study On Orientalist Views", International Journal Of Academic Research In Business And Social Sciences, 7(8), 2017, 39-45.

${ }^{6}$ A. H. Bahruddin, Mujahidin, E., \& Hafidhuddin, D, "Metode Tahfizh Al-Quran Untuk Anak-Anak Pada Pesantren Yanbu'ul Qur'an Kudus Jawa Tengah", Ta'dibuna, 6(2), 2018, 65-75. 
Bagi sebagian peneliti, Bangsa Arab dianggap sebagai Bangsa yang cenderung tidak menyukai baca tulis ${ }^{7}$, namun faktanya, hal tersebut juga menjadi nilai tambah bagi Bangsa Arab dalam hal periwayatan al-Qur'an. Karena tidak terlalu suka menulis, Bangsa Arab akhirnya lebih banyak mengandalkan hafalannya ${ }^{8}$. Sehingga Bangsa Arab secara umum memiliki hafalan yang kuat, karena telah terlatih untuk menghafal. Mereka menghafal silsilah keluarga mereka, sya'ir-sya'ir, puisi, dan juga kisah-kisah penting dalam kebudayaan mereka. Mereka juga senang berpindah-pindah ${ }^{9}$, sehingga mereka juga tidak terlalu suka menyimpan buku dan tulisan, karena cenderung akan menyulitkan mereka saat melakukan pindahan. Maka saat alQur'an turun, Bangsa Arab sudah memiliki kesiapan untuk menampung dan menyimpan setiap ayat al-Qur'an di dalam memori mereka yang kuat dan terlatih, hingga kemudian mereka sebarkan dan kabarkan ke seluruh penjuru Dunia. Maka benarlah ayat Allah Saw dalam kitabNya:

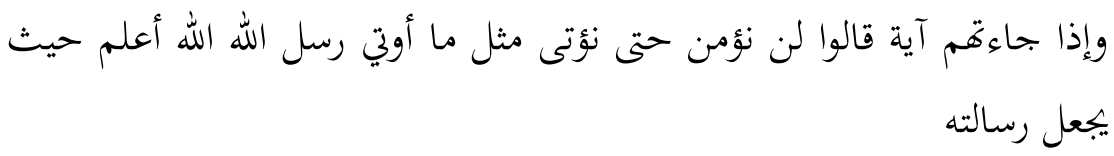

Artinya: Dan ketika datang ayat kepada mereka, mereka berkata, "Kami tidak akan beriman, sampai kami diberikan yang semisal dengan apa yang diberikan kepada Rasul-Rasul Allah. Allah lebih tahu, di mana Dia seharusnya menurunkan RisalahNya. (QS. al-An'am: 124).

Al-Qur'an bukanlah satu-satunya kitab suci agama samawi. Kitab suci lain yang masih ada sampai sekarang adalah Taurat, Zabur dan Injil ${ }^{10}$. Namun jika dibandingkan antara ketiga kitab suci tersebut, tentu saja keaslian dan kemurnian teks alQur'an sebagai Kalam Tuhan memiliki superioritas yang sulit dibantah. Al-Qur'an memiliki sejarah periwayatan dan pembukuan yang lengkap.

${ }^{7}$ I. S. Wekke, Tamimi, R. H., \& Sugandi, B, "Muhammad Saw dan Peletakan Dasar Peradaban Islam", Aqlam: Journal Of Islam And Plurality, 3(1), 2018.

${ }^{8}$ I. S. Wekke, , Tamimi, R. H., \& Sugandi, B, "Muhammad Saw Dan Peletakan Dasar Peradaban Islam", Aqlam: Journal Of Islam And Plurality, 3(1), 2018.

${ }^{9}$ Taufik, M. H. N., Isnaini, N., \& Khumairoh, R, "Urgensi Keluarga Dalam Masyarakat Arab", Semnasbama, 2, 2018.

${ }^{10}$ Siahaan, D. S, "Ketika Aku dan Kamu Menjadi Kita: Dialog Misi Penginjilan Kristen Dengan Dakwah Islam Menggunakan Pendekatan Teologi Interkultural Dalam Konteks Indonesia”, Gema Teologika, 2(1), 2017, 41-54. 
Bahkan tidak ada campur aduk antara Perkataan Tuhan dan perkataan Nabi Muhammad di dalam al-Qur'an. Berbeda dengan injil misalnya, yang ditulis oleh Para Murid Nabi Isa, yang masing-masing juga memasukkan perkataan Nabi Isa dan sahabat-sahabatnyanya di dalam teks injil. ${ }^{1}$

Hal lain yang membuat al-Qur'an menjadi lebih universal dan jelas, adalah fakta bahwa Bahasa al-Qur'an, Bahasa Arab masih digunakan sebagai Bahasa Resmi di banyak Negara di Dunia $^{12}$. Al-Qur'an juga dibaca dan dikaji oleh Umat Islam di seluruh Dunia dengan Bahasa Arab, sehingga tidak tejadi bias dalam penyampaian dan pemahaman. Berbeda dengan injil yang diyakini teks aslinya menggunakan Bahasa Ibrani ${ }^{13}$, Aram ${ }^{14}$, dan Koine (Yunani Kuno) ${ }^{15}$. Ketiga bahasa tersebut sudah jarang dipelajari, sehingga cetakan yang beredar jarang menggunakan Bahasa tersebut. Hal ini mengakibatkan kurangnya perhatian masyarakat awam terhadap teks asli injil, sehingga proses periwayatan suara dan tulisan tidak dapat diakses dengan lebih maksimal. Hal ini bisa jadi dikarenakan jarak yang cukup jauh antara masa Nabi Isa dan masa kita sekarang.

Karena sulitnya mengakses informasi dari Bahasa Asli injil, maka Umat Kristen tidak dapat melakukan penafsiran sendiri. Mereka sangat bergantung kepada penafsiran gereja. Hal inilah yang kemudian juga menimbulkan perpecahan dalam tubuh masyarakat Kristen, terutama sekali setelah kemunculan Martin Luther dan Kaum Protestan ${ }^{16}$, sehingga mayoritas Umat Kristen

${ }^{11}$ N. Sarumaha, "Eskatologi Dalam Injil Markus", Epigraphe: Jurnal Teologi Dan Pelayanan Kristiani, 1(2), 2018, 104-118.

12 A. H. Hanafi, "Lembaga Pendidikan Tinggi Islam: Harapan, Tantangan, Paradigma, dan Peranan Bahasa Arab", Al-Fikrah: Jurnal Manajemen Pendidikan, 1(1), 2016, 17-28.

${ }^{13}$ David Aberbach, "Introduction." In The Bible And The'holy Poor', Pp. 9-21. Routledge, 2017.

${ }^{14}$ E. K. Aribowo, “Aspek-Aspek Linguistis Penanda Identitas Religi: Selayang Pandang Masyarakat Tutur Jawa Muslim”, In Seminar Nasional dan Launching Adobsi. Surakarta: Asosiasi Dosen Bahasa dan Sastra Indonesia (Adobsi), 2015, April, Pp. 48-53.

${ }^{15}$ E. A. Sinukaban, "Prinsip Hidup Jemaat Mula-Mula Dalam Kisah Para Rasul", 2: 41-47, Pneustos: Jurnal Teologi Pantekosta, 1(1), 2018, 43-57.

${ }^{16}$ D. Cantoni, "The Economic Effects Of The Protestant Reformation: Testing The Weber Hypothesis In The German Lands", Journal Of The European Economic Association, 13(4), 2015, 561-598. 
terpecah antara Kristen Katolik dan Protestan, di samping AliranAliran lain yang sudah ada seperti Koptik dan Ortodoks ${ }^{17}$.

Kaum Katolik secara umum menyerahkan penafsiran injil sepenuhnya kepada gereja. Mereka bahkan melarang pengikutnya untuk menasirkan injil secara bebas. Meskipun hal itu jelas sulit karena ketidakmampuan sebagian besar Umat Kristen Katolik memahami Bahasa Asli Injil. Sebaliknya, Kaum Protestan menentang monopoli gereja terhadap teks Injil. Mereka menuntut agar penafsiran injil menjadi hak setiap pemeluk agama kristen, agar tidak terjadi doktrin yang sepihak dan tidak logis dari pihak gereja.

Berbeda dengan penafsiran Injil, penafsiran al-Qur'an menjadi sangat penting dan bermanfaat, karena teks asli alQur'an masih sangat dikenal oleh Umat Islam di seluruh Dunia. Teks al-Qur'an beserta audionya dapat kita akses dengan mudah di internet, dan semua menggunakan Bahasa Arab, Bahasa Asli Nabi Muhammad Saw. Teks dengan Bahasa Arab tersebut tentu saja membutuhkan penjelasan-penjelasan yang lebih rinci dan jelas, karena sebagian Umat Islam belum memahami Bahasa Arab dengan sempurna, selain itu, terdapat berbagai kosa kata Bahasa Arab yang jarang digunakan di dalam teks biasa, sehingga untuk memahaminya membutuhkan bantuan pakar-pakar yang lebih paham tentang kandungan teks tersebut.

Sebagian peneliti bahkan meyakini, bahwa sesungguhnya turunnya al-Qur'an tidak hanya melalui satu tahapan, namun beberapa tahapan. Tahapan pertama ialah turunnya al-Qur'an satu kali turun dari langit ketujuh menuju langit dunia atau Baitul Izzah $^{18}$. Tahapan kedua dilanjutkan oleh Jibril, yaitu menurutkan al-Qur'an dari Baitul Izzah ke dalam hati Nabi Muhammad Saw $^{19}$. Tahapan ketiga, ialah proses penafsiran al-Qur'an oleh Umat Islam sendiri, yang kemudian diajarkan kepada seluruh Umat Manusia $^{20}$.

${ }^{17}$ Harun Dündar Karahan, "Understanding Of Revelation In Christian Sects." Bozok University Journal Of Faculty Of Theology [Bozifder] 13, No. 13, 2018, 13.

${ }^{18}$ T. Muttaqin, "Khazanah Ulama Nusantara: Tafsir Murāh Labīd Karya Nawawi Banten, Al-A'raf: Jurnal Pemikiran Islam Dan Filsafat, 12(2), 2015, 11-20.

${ }^{19}$ H. S Nasution, "Epistemologi Question: Hubungan Antara Akal, Penginderaan, Intuisi dan Wahyu dalam Bangunan Keilmuan Islam", Almufida, 2016, 1(1).

20 A. Saeed, al-Qur'an Abad 21: Tafsir Kontekstual, Terj. Ervan Nurtawab, (Bandung: Mizan, 2016). 
Proses terakhir inilah yang berlangsung berabad-abad lamanya. Maka sesungguhnya proses turunnya al-Qur'an masih terus belangsung, terutama proses turunnya wahyu ke dalam hati dan pikiran setiap Umat Manusia.

Hal menarik dari tahapan yang ketiga, ialah bahwa ternyata teks al-Qur'an bisa memiliki makna yang beragam, jika ditafsirkan oleh orang yang berbeda. Bahkan ayat al-Qur'an juga bisa memiliki makna yang berbeda jika ditafsirkan di zaman yang berbeda $^{21}$. Sehingga pemaknaan al-Qur'an menjadi suatu kajian yang tidak ada habisnya, karena selalu berkembang dan berkembang dari masa ke masa. Penafsiran al-Qur'an juga membutuhkan pembaharuan, seiring dengan perubahanperubahan yang terjadi di dalam masyarkat. Meskipun tentu saja, perubahan-perubahan yang ada dalam penafsiran harus tetap sejalan dengan apa yang telah ditafsirkan oleh para mufassir terdahulu, yang secara periodik lebih dekat dengan zaman Nabi, agar tidak terjadi penyelewengan dalam penafsiran al-Qur'an.

Proses penafsiran al-Qur'an sesungguhnya sudah dimulai sejak zaman Nabi Muhammad Saw. Dilanjutkan oleh Para Sahabat Nabi, Tabi'in, dan dilanjutkan oleh Para Ulama Muslim dari masa ke masa. Hingga kini penafsiran al-Qur'an telah dikumpulkan dalam bentuk buku dalam jumlah yang cukup banyak, dengan ragam corak dan macamnya ${ }^{22}$.

Para pakar dan cendekiawan Muslim dari setiap generasi selalu melahirkan karya baru dalam Ilmu Tafsir, Mulai dari karya Ulama periode klasik, pertengahan, hingga modern. Corak dan ragamnya juga banyak, ada penafsiran dengan menggunakan teks al-Qur'an, Hadits, dan riwayat Para Sahabat (tafsir bi al-ma 'tsur), seperti kitab tafsir karya Ibnu Jarir At-Thabari (wafat 310 H) dan Ibnu Katsir (wafat $774 \mathrm{H})^{23}$. Selain itu, ada pula penafsiran dengan menggunakan pemikiran dan logika (tafsir bi ar-ra'yi) ${ }^{24}$, seperti tafsir Al-Manar karya Imam Muhammad Abduh (wafat 1323 H) dan Rasyid Ridha (wafat 1354 H).

${ }^{21}$ A. Atabik, "Perkembangan Tafsir Modern di Indonesia", Dalam Jurnal Hermeunetik, 8(2), 2014.

${ }^{22}$ Abdullah, A, "Metodologi Penelitian, Corak Dan Pendekatan Tafsir Al Qur'an", Journal Al-Manar, 6(1), 2017.

${ }^{23}$ A. H. Nasution, \& Mansur, "M. Studi Kitab Tafsīr Al-Qur'ān AlAzimm Karya Ibnu Kasir", Jurnal Ushuluddin Adab Dan Dakwah, 1(1), 2018, $1-14$.

${ }^{24}$ A. Z. A. Zainuddin, “Tafsir Bi Al Ra'yi”, Mafhum, 1(1), 2017, 73-86. 
Sebagian buku tafsir bahkan memiliki fokus yang yang berbeda, seperti tafsir dengan analisa nahwu (i'rab) karya Muhyiddin Ad-Darwisy (Wafat $1403 \mathrm{H}$ ). Ada pula Tafsir dengan analisa Balaghah seperti tafsir Al-Kasyaf karya Az-Zamakhsyari (wafat $467 \mathrm{H})^{25}$, dan juga tafsir dengan analisa sastra, seperti AtTafsir Al-Bayani karya Aisyah Bintu Syathi' (wafat 1419 H) ${ }^{26}$.

Semua penafsiran yang dihasilkan oleh Umat Islam tersebut, bermula dari usaha penafsiran yang dilakukan oleh Para Sahabat Nabi. Mereka adalah orang-orang pertama yang melakukan tadabbur dan tafakkur terhadap ayat-ayat al-Qur'an. Mereka bahkan menanyakan langsung kepada Rasulullah Saw jika mereka mendapati ayat-ayat yang menurut mereka sulit untuk dipahami. Maka tentu saja, mufassir pertama dalam sejarah, setelah Rasulullah Saw, adalah para sahabat. Melalui Para Sahabat Nabi tersebut, Umat Islam kemudian mendapatkan pemahaman yang lebih baik tentang ayat-ayat al-Qur'an.

Selanjutnya, kita tentu ingin menjawab pertanyaanpertanyaan yang berkaitan dengan penafsiran Para Sahabat ini, misalnya tentang, apakah penafsiran Para Sahabat mencakup seluruh isi al-Qur'an, ataukah hanya sebagian? Lalu apakah penafsiran Para Sahabat sepenuhnya merupakan hasil konsultasi dengan Nabi Muhammad, ataukah merupakan hasil pemikiran dan ijtihad sendiri dari Para Sahabat? Selanjutnya, apakah semua riwayat yang mengandung penafsiran Para Sahabat memiliki nilai yang sama dalam hal kesahihan, ataukah penafsiran tersebut berbeda-beda tingkatan reliabilitasnya? Apakah ada penafsiran yang sahih atau maudu? Lalu bagaimana proses kodifikasi penafsiran Para Sahabat tersebut? Apakah semua penafsiran tersebut hanya berbentuk lisan, ataukah sudah ada yang berbentuk tulisan, dan kapan penafsiran tersebut ditulis? Lalu apa sajakah usaha yang dilakukan oleh Abdullah bin Abbas dalam menafsirkan al-Qur'an? Penulis berharap, pertanyaan-pertanyaan tersebut dapat kita jawab melalui artikel ini.

${ }^{25}$ R. Gharro, Pakaian dalam Al-Qur'an Perspektif Zamakhsyari dalam Tafsir Al Kasyaf: Telaah Penafsiran Kata Libas, Thiyab dan Sarabil (Doctoral Dissertation, Uin Sunan Ampel Surabaya), 2018.

${ }^{26}$ S. I. A. Azis, Pandangan Bintu Syathi Tentang Qasam: Studi Kitab Al-Tafsir Al-Bayani Lil Qur'an Al-Karim (Doctoral Dissertation, Uin Raden Intan Lampung), 2018. 


\section{B. Biografi Abdullah bin Abbas}

Abdullah bin Abbas lahir pada saat Bani Hasyim mengalami pemboikotan di Mekkah. Yaitu antara tahun ke-7 sampai ke-10 kenabian ${ }^{27}$. Ia lahir dengan nama Abdullah bin Abbas bin Abdul Muttalib bin Hasyim bin Abdi Manaf. Ia tumbuh di dalam keluarga yang terhormat di Masyarakat Quraisy. Abdu Manaf adalah pemimpin Quraisy yang sangat disegani, begitu pula hasyim dan Abdul Muttalib. Sebagaimana kakek dan buyutnya, saat ia kecil ayahnya Abbas juga mendapat kehormatan sebagai penjaga Ka'bah yang bertugas melayani tamu-tamu yang datang untuk melaksanakan haji yang biasa disebut dengan (siqayat al-haj).

Ayahnya, Abbas menjadi wajah dari Bani Hasyim, terutama setelah wafatnya Abu Thalib, sehingga kepemimpinan Bani Hasyim dan pengasuhan Rasulullah Saw menjadi tanggung jawab Abbas, meskipun hal tersebut tidak ditampakkan dengan terang-terangan. Karena itu pula, Abbas, meskipun saat itu belum menyatakan keislamannya, ikut pula menghadiri Bai'at Aqabah, hal itu tidak lain adalah untuk mengamankan dan mendukung Rasulullah Saw. Lebih dari itu, saat Rasulullah Saw telah hijrah ke Madinah, pamannya, Abbas juga menjadi mata-mata Rasulullah Saw di Mekkah. Meskipun ia ikut terlibat dalam Perang Badar, namun hal itu hanyalah untuk menjaga hubungan baiknya dengan Pimpinan Masyarakat Quraisy, yaitu Abu Sufyan $^{28}$.

Sedangkan Ibu dari Ibnu Abbas ialah Lubabah binti AlHaritsah. Bibi beliau dari pihak ibu, ialah ibu dari Khalid bin Walid. Sedangkan Bibinya yang kedua dari pihak ibu menikah dengan Usamah Abi Syadad. Lalu Bibinya yang ketiga, Maymunah merupakan istri dari Rasulullah $\mathrm{Saw}^{29}$.

Abdullah bin Abbas tumbuh di dalam lingkungan yang mencintai Rasulullah Saw. Tentu saja hal tersebut karena beliau adalah sepupu dari Rasulullah Saw. Ia telah masuk islam secara sembunyi-sembunyi sebelum terjadinya fathu Mekkah. Setelah Fathu Mekkah terjadi pada tahun ke-8 Hijriyah, Ibnu Abbas selalu menemani Rasulullah Saw.

27 Ibnu Abdi Al-Bar, Yusuf Abdullah Muhammad, Al-Isti'ab Fi Ma'rifati Shahabah, Tahqiq Muhammad Ali Al-Bukhari, Jilid 3, (1992) Hal. 933.

${ }^{28}$ Salim Abdu Ali, Abdullah Bin Abbas Dirasat Fi Siratihi Wa Daurihi. Adab Ar-Rafidin, Edisi 65, 2013, 199-210.

${ }^{29}$ Ibnu Qutaybah, Kitabul Ma'arif, (T.tp: tp, tt), 282. 
Bahkan sedemikian seringnya beliau menemani Rasulullah Saw, sampai-sampai ia melihat Jibril lebih dari satu $\mathrm{kali}^{30}$. Rasulullah Saw juga mendo'akan Ibnu Abbas lebih dari dua kali agar dikaruniai kefaqihan dan hikmah ${ }^{31}$.

Karena itulah, Abdullah bin Abbas banyak mendengar langsung hadits-hadits yang disampaikan oleh Rasullah Saw. Beliau merupakan salah satu Sahabat Nabi yang paling banyak meriwayatkan hadits. Secara umum, beliau menempati urutan keempat, setelah Abu Hurairah, Abdullah bin Umar, dan Jabir bin Abdullah. Total, terdapat sekitar 1660 hadits yang beliau riwayatkan. Di dalam kitab Sahih Bukhari dan Sahih Muslim, terdapat 75 hadits yang diriwayatkan, dan terdapat 197 perawi yang meriwayatkan hadits dari beliau ${ }^{32}$.

Abdullah bin Abbas tidak hanya mengambil ilmu dari Rasulullah Saw. Ia juga belajar dari Ulama-Ulama yang ada di antara Para Sahabat, untuk mengambil ilmu-ilmu agama yang belum ia dapatkan sebelumnya. Abdullah bin Abbas juga sangat terkenal karena sopan santunnya. Ketika ia berkunjung ke suatu rumah, untuk belajar kepada Para Sahabat, ia tidak mengetuk pintunya, namun ia menunggu sampai Para Sahabat tersebut keluar dari rumahnya, barulah ia dapat menemui mereka ${ }^{33}$.

Karena semangatnya yang sangat tinggi untuk belajar, dan karena ketinggian budi pekertinya, Abdullah bin Abbas dipujipuji oleh Para Sahabat, antara lain oleh Abu Bakr, Umar, Utsman, Ali dan Aisyah $^{34}$. Lebih dari itu, jika Para Sahabat berbeda pendapat tentang suatu masalah dengan Abdullah bin Abbas, mereka akan condong mengikuti pendapat Abdullah bin Abbas, karena mereka mengetahui kedalaman ilmu Abdullah bin Abbas. Dalam banyak fatwa dan pendapatnya, Abdullah bin Abbas juga memperkuatnya dengan Hadits Rasullah Saw.

${ }^{30}$ Ibnu Sa'd, At-Thobaqat Al-Kubro, Maktabatul Khanji, Jilid 2, 2001, $365,367,371$.

${ }^{31}$ Salim Abdu Ali, Abdullah Bin Abbas Dirasat fi Siratihi Wa Daurihi, Adab Ar-Rafidin, Edisi 65. 2013, 199-210.

${ }^{32}$ Salim Abdu Ali, Abdullah Bin Abbas Dirasat Fi Siratihi Wa Daurihi, Adab Ar-Rafidin, Edisi 65. 2013, 199-210.

${ }^{33}$ Az-Zahabi, Siyar A 'lam Nubala, Baitul Afkar Al-Waliyyah. Tahqiq Hassan Abdul Mannan, Jilid 3, 2009, 358.

${ }^{34}$ Al-Asqolani, Ahmad Bin Ali Bin Muhammad Bin Ahmad Bin Hajar, Al-Ishobah Fi Tamyizi As-Shahabah, Jilid 2 (Beirut: Darul Kutub, 1995), 331. 
Karena keistimewaannya dalam ilmu-ilmu keislaman, maka tidak aneh jika ia kemudian dijuluki dengan Lautan Ilmu (al-bahr), Tinta Umat Islam (hibru al-ummah), Manusia Robbani (robbaniyyu al-ummah) dan Penerjemah al-Qur'an (turjuman alQur'an) ${ }^{35}$.

Abdullah bin Abbas memiliki kesungguhan yang luar biasa dalam mencari informasi. Ia menyatakan, bahwa untuk mendapatkan satu ilmu, ia akan mendatangi lebih dari 33 Sahabat. Hal ini untuk mengambil semua pendapat Sahabat yang bisa jadi berbeda, meskipun semua ilmu tersebut mereka dapatkan dari Rasulullah $\mathrm{Saw}^{36}$. Karena itu, para pakar dan ahli hadits menganggap Abdullah bin Abbas sebagai salah satu perawi yang terpercaya. Setelah wafatnya Rasulullah Saw, Abdullah bin Abbas hijrah ke Mekkah, di sana ia mengajarkan ilmu yang dimilikinya kepada murid-muridnya di Mekkah.

Abdullah bin Abbas juga memiliki peran yang penting dalam mendukung khilafah Abu Bakr, Umar, Usman, Ali dan Muawiyah. Abdullah bin Abbas juga dikenal sebagai pendukung Daulah Bani Umayyah, karena memang nasab mereka (Bani Hasyim) bertemu dengan Bani Umayyah pada Abdu Manaf. Ia juga bahkan menolak untuk mendukung Husein, saat ia ingin keluar dari barisan, untuk menentang Yazid bin Muawiyah dan bergabung bersama para pendukungnya di Iraq.

Beliau juga menentang kekhalifahan Abdullah bin Zubair yang melakukan pemberontakan di Mekkah dan Madinah, hingga ia terpaksa hijrah dari Mekkah ke Thoif. Di Thoif ia tetap mendukung Daulah Bani Umayyah, ia juga melakukan suratmenyurat dengan Khalifah Bani Umayyah, Abdul Malik bin Marwan. Hingga akhirnya ia wafat di Thoif pada tahun $68 \mathrm{H}$, di usia sekitar 70 tahun. Dalam referensi sejarah, disebutkan bahwa saat pemakamannya, muncul seekor burung berwarna putih, yang dikatakan itu adalah perwujudan ilmu Abdullah bin Abbas, dan terdengar suara ayat al-Qur'an tanpa ada yang tahu, siapa yang membacakannya ${ }^{37}$, ayat yang dibaca tersebut ialah:

${ }^{35}$ Ibnu Sa'd, At-Thobaqat al-Kubro (Kairo: Maktabatul Khanji, 2001), 365-368.

${ }^{36}$ Ibnu Sa'd, At-Thobaqat al-Kubro (Kairo: Maktabatul Khanji, 2001), 367.

${ }^{37}$ Al-Andalusi, Abdul Malik Bin Habib Abi Marwan As-Sulmi, Kitab Al-Mihbar, (Jam'iyyat Dairotul Ma'arif Al-Utsmaniyah, 1361 H), 296. 


$$
\text { وادخلي أيتها النفس المطمئنة ارجعي إلى ربك راضية مرضة. فادخلي في عبادي، }
$$

Artinya: Wahai jiwa yang tenang, kembalilah kepada Tuhanmu dengan ridho dan diridhoi, maka masuklah ke dalam golongan hambaKu, dan masuklah ke Surgaku. (QS. al-Fajr: 28$30)$.

\section{Nuskhah Haditsiyah Tafsiriyah}

Untuk memahami penafsiran yang dilakukan oleh Para Sahabat, kita juga harus melakukan penelitian terhadap catatancatatan penafsiran Para Sahabat yang biasa disebut dengan nuskhah. Secara Bahasa, nuskhah (نُشَنَ) memiliki makna, tulisan

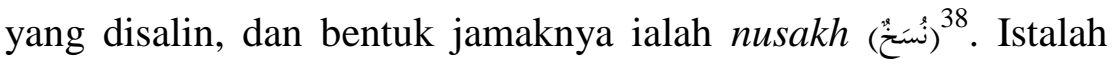
lain yang juga sering digunakan adalah shahifah (صَحِيَغَ) secara makna hata ini memiliki makna: catatan berbentuk kulit atau kertas jamaknya ialah shuhuf (صُحُقِق(صُ). Pada mulanya, shahifah berbentuk satu kertas, kemudian diartikan sebagai kumpulan kertas, untuk mewakili bentuk jamaknya, karena itulah kumpulan tulisan juga bisa disebut sebagai nusakh ${ }^{39}$.

Secara istilah, shahifah ialah satu lembaran yang berisi satu hadits atau lebih. Yang semuanya memiliki satu sanad. Secara umum, shahifah tidak hanya mengandung satu bab tertentu, namun juga mencakup lebih dari satu bab. Sedangkan istilah nuskhah, merupakan sinonim dari shahifah. Karena penggunaan keduanya bisa dilakukan dalam konteks yang sama ${ }^{40}$.

Nusakh haditsiyah jumlahnya sangat banyak. Selain itu, terdapat pula kumpulan nusakh yang mengandung tafsir. Sebagian ada yang dicatat dari Para Sahabat, dan sebagian yang lain dicatat dari Para Tabiin. Para Sahabat yang terkenal dengan tafsirnya antara lain: Para Khulafaurrasidin, Ibnu Mas'ud, Ibnu Abbas, Ubay bin Ka'ab, Zaid bin Tsabit, Abu Musa Al-Asy'ari, Abdullah bin Zubair ${ }^{41}$.

${ }^{38}$ Al-Fayumi, Al-Misbah Fi Gharib As-Syarh Al-Kabir (Beirut: Darul Fikr, 2015), 334.

${ }^{39}$ Bakr Abu Zayd, Ma'rifatu An-Nusakh wa Shuhuf Haditsah (Daru ArRoyah, 1992), 22.

${ }^{40}$ Bakr Abu Zayd, Ma'rifatu An-Nusakh wa Shuhuf Haditsah (Daru ArRoyah, 1992), 23.

${ }^{41}$ As-Suyuti, Jalaluddin, Al-Itqan fi Ulum al-Qur'an, Jilid 4, (Majma' Malik Fahd, 1426 H), 207-210. 
Dan Sahabat yang paling banyak riwayatnya dalam tafsir, ialah Abdullah bin Abbas. Abdullah bin Abbas dianggap telah melahirkan kelompok muslim intelektual karena banyaknya murid dan pengikutnya. Sebagian dari mereka adalah orang-orang yang terpercaya dan merupakan penghafal-penghafal hadits, sedangkan sebagian yang lain dianggap lemah secara periwayatan.

Sebagian dari murid Abdullah bin Abbas meriwayatkan nusakh berisi tafsir yang diriwayatkan dari Abdullah bin Abbas ${ }^{42}$. Antara lain:

1) Mujahid bin Jabar, ia meriwayatkan tafsir dari Abdullah bin Abbas, melalui jalur Ibnu Abi Najih dari Mujahid, dan jalur Ibnu Abi Najih dianggap kuat ${ }^{43}$.

2) Ikrimah yang meriwayatkan melalui jalur Al-Hasan bin Waqid dari Yazid An-Nahwi, dan melalui Muhammad bin Ishaq dari Muhammad bin Abi Muhammad, hamba Zaid bin Tsabit dari Ikrimah, atau Said bin Jabir.

3) Muawiyah bin Shalih dari Ali bin abi Tholhah dari Ibnu Abbas. Ini adalah teks yang akan menjadi pembahasan kita dalam artikel ini.

4) Ibnu Jarij dari Atho' bin Abi Robbah dari Abdullah bin Abbas, yang berkaitan dengan surat Al-Baqarah, Ali Imran, dan lain sebagaiinya. Meskipun sanadnya ada yang terputus ${ }^{44}$.

Di antara perawi tafsir Abdullah bin Abbas, yang dianggap lemah anara lain ${ }^{45}$ :

1) Abu Nadhor Muhammad bin As-Saib Al-Kalbi, diriwayatkan oleh Abu Sholih, hamba dari Ummu Hani, dari Abdullah bin Abbas. Dan Al-Kalbi dituduh pembohong. Meskipun begitu riwayat ini juga beredar dan diriwayatkan oleh perawi-perawi lainnya, seperti Muhammad bin Marwan As-Sayyid, diriwayatkan juga oleh Sholeh bin Muhammad At-Tirmizi ${ }^{46}$.

${ }^{42}$ As-Suyuti, Jalaluddin, al-Itqan fi Ulum al-Qur'an, Jilid 4, (Majma' Malik Fahd, 1426 H), 207-210.

${ }^{43}$ As-Suyuti, Jalaluddin, al-Itqan fi Ulum al-Qur'an, Jilid 4, (Majma' Malik Fahd, 1426 H), 207-210.

${ }^{44}$ As-Suyuti, Jalaluddin, al-Itqan fi Ulum al-Qur'an, Jilid 4, (Majma' Malik Fahd, 1426 H), 207-210.

${ }^{45}$ As-Suyuti, Jalaluddin, al-Itqan fi Ulum al-Qur'an, Jilid 4, (Majma' Malik Fahd, 1426 H), 207-210.

${ }^{46}$ As-Suyuti, Jalaluddin, al-Itqan fi Ulum al-Qur'an, Jilid 4, (Majma' Malik Fahd, 1426 H), 207-210. 
2) Ad-Dhohak bin Muzahim, ia bisa dipercaya, namun ia tidak mendengar langsung dari Abdullah bin Abbas, namun ia meriwayatkan dari Jubir bin Sa'id, dan dia dianggap tidak bisa dipercaya ${ }^{47}$.

3) Usman bin Atho' Al-Khurasani, ia meriwayatkan tafsir dari ayahnya dari Abdullah bin Abbas, namun ayahnya tidak mendengar langsung dari Ibnu Abbas.

4) Ismail bin Abdurahman As-Suddiy, ia adalah orang Kufah yang bisa dipercaya, namun ia meriwayatkan tafsir dengan mencampur antara Abi Sholih dari Abdullah bin Abbas, dan dari Marrah bin Syarahil, dari Ibnu Mas'ud, dan dari Para Sahabat lainnya, semua riwayat tafsir tersebut dicampur menjadi satu, dan belum dibedakan antara riwayat yang kuat dan lemah. Dan As-Suddiy juga tidak bertemu dengan sahabat, kecuali Anas bin Malik.

5) Ibrahim bin Al-Hakam bin Aban Al-Adani, dan ia lemah, ia meriwayatkan tafsir dari ayahnya, dari Ikrimah.

6) Atho' bin Dinar, ia meriwayatkan tafsir dari Sa'id bin Jabir dari Ibnu Abbas, dan ia meriwayatkan dari Ibnu Lah'ah dan ia doif.

Itulah tadi jalur-jalur periwayatan tafsir Abdullah bin Abbas yang ditulis oleh para perawi dalam nusakh. Riwayatriwayat tafsir Ibnu Abbas tersebut kemudian ditulis oleh Para Mufassir. Terdapat empat orang mufassir yang menggunakan penafsiran Abdullah bin Abbas, yaitu ${ }^{48}$ :

1) Tafsir Imam Abi Ja'far bin Jarir At-Thobary

2) Tafsir Imam Abu Bakr Muhammad bin Ibrahim bin AlMundzir An-Nisaburi

3) Tafsir Abu Muhammad Abdurrahman bin Abi Hatim Ar-Rozi

4) Tafsir Abdu bin Humaid bin Nashr Al-Kusysyi.

47 Jalaluddin As-Suyuti, al-Itqan fi Ulum al-Qur'an, Jilid 4 (Majma' Malik Fahd, 1426 H), 207-210.

${ }^{48}$ Salim Abdu Ali, Abdullah Bin Abbas Dirasat Fi Siratihi wa Daurihi, Adab Ar-Rafidin, Edisi 65, 2013, 199-210. 
Keempat tafsir tersebut merupakan tafsir yang menghimpun riwayat-riwayat tafsir para sahabat. Informasi yang dimuat dalam tafsir-tafsir tersebut juga dianggap cukup kuat. Tafsir At-Thobari memiliki kelebihan di antara yang lain, karena Imam At-Thobari memasukkan beberapa perbedaan becaan dalam beberapa qira'at yang mungkin dapat menimbulkan perbedaan dalam penafsiran. Apa yang dimuat oleh Imam AtThobari tidak lagi dimuat oleh mufassir-mufassir setelahnya ${ }^{49}$.

\section{Nuskhah Ali Bin Abi Tholhah}

Sebelum membahas tentang nuskhah yang diriwayatkan oleh Ali bin Abi Tholhah, penulis ingin membahas secara singkat tentang beliau. Ia adalah Ali bin Abi Tholhah, ia tinggal di Jazirah Arab, dan kemudian hijrah ke daerah $\mathrm{Hams}^{50}$. Ia mengambil ilmu dari beberapa tabi'in antara lain: Sa'id bin Jajir (wafat $94 \mathrm{H}$ ), Mujahid bin Jabir (wafat $103 \mathrm{H}$ ), Al-Qasim bin Muhammad (wafat $107 \mathrm{H}$ ), Abu Al-Waddak Jabar bin Nuf AlHamdani, Rasyid bin Sa'd Al-Hidani (wafat 108 H), Ikrimah mawla Ibnu Abbas (wafat $105 \mathrm{H}$ ).

Ali bin Abi Tholhah terkenal dengan keilmuannya, terutama dalam bidang hadits dan tafsir. Imam Muslim dalam sahihnya juga mengambil riwayat dari beliau, termasuk juga Abu Daud, An-Nasa'i, dan Ibnu Majah dalam kitab-kitab sunan mereka. Ia wafat di Hams tahun $143 \mathrm{H}^{51}$. Mengenai kedudukannya, menurut para ahli hadits, cukup seimbang. Sebagian memujinya, dan menganggapnya sebagai sosok yang bisa dipercaya, sedangkan sebagian yang lain menggapnya termasuk perawi yang lemah (dhoif).

${ }^{49}$ Salim Abdu Ali, Abdullah Bin Abbas Dirasat fi Siratihi wa Daurihi. Adab ar-Rafidin, Edisi 65, 2013, 199-210.

${ }^{50}$ Salim Abdu Ali, Abdullah Bin Abbas Dirasat fi Siratihi wa Daurihi. Adab ar-Rafidin. Edisi 65, 2013, 199-210.

${ }^{51}$ Salim Abdu Ali, Abdullah Bin Abbas Dirasat fi Siratihi wa Daurihi. Adab Ar-Rafidin, Edisi 65, 2013, 199-210. 
Sedangkan sebagian yang lain menempatkan dirinya diantara keduanya, tidak menganggap riwayatnya lemah, tidak pula kuat. Sebagian dari pendapat ahli hadits antara lain ${ }^{52}$ :

1) Imam Ahmad berkata: "Ia memiliki hal-hal yang mungkar".

2) Abu Daud berkata: "Ia in sya Allah lurus haditsnya, namun ia memiliki pendapat yang buruk, ia memiliki pendapat pedang". Imam Abu Daud ialah bahwa ia mendukung penyerangan terhadap orang-orang yang berbuat buruk.

3) An-Nasa'i berkata: "Ia tidak bermasalah".

4) Dahim berkata: "Ia belum mendengar tafsir dari Ibnu Abbas".

5) Ya'qub bin Sufyan berkata: "Ia lemah haditsnya, munkar", di tempat lain ia berkata: "Ia orang syam, perkataannya tidak ditinggalkan, dan tidak pula bisa dijadikan hujjah".

6) Ibnu Hibban memasukkannya kedalam golongan tsiqat (bisa dipercaya), ia juga berkata bahwa Ali bin Abi Tholhah meriwayatkan dari Ibnu Abbas, dan ia belum melihat Ibnu Abbas.

7) Al-Hafizh Ibnu Hajar mengambil kesimpulan tentang Ali bin Abi Tholhah dengan berkata: "Ia bisa dipercaya, dan terkadang melakukan kesalahan".

Jika kita melihat pendapat-pendapat para ahli hadits di atas, kita dapat mengambil kesimpulan, bahwa sesungguh Ali bin Abi Tholhah adalah sosok yang cukup baik dalam kalangan ahli hadits. Kebanyakan dari mereka menganggap Ali bin Abi Tholhah kurang baik dikarenakan keyakinannya untuk memerangi pemimpin yang berlaku buruk. Padahal kebanyakan Ulama meyakini bahwa Rasulullah Saw lebih menekankan pentingnya bersabar menghadapi pemimpin yang zholim. Imam Abu Ja'far At-Thohawi juga menyatakan bahwa: "kami tidak memandang perlunya memerangi pemimpin (waliyul amri), meskipun mereka berperilaku buruk" ${ }^{, 53}$. Meskipun Ali bin Abi Tholhah memiliki pendapat dan ijtihad yang kurang baik dalam hal ini, namun hal ini secara umum tidak mengurangi kredibilitasnya sebagai seorang yang cukup dipercaya dalam hal periwayatan hadits.

52 Ibnu Hajar Al-Asqolany, Tahdzibu At-Tahdzib, Jilid 3 (T.tp: alMa'arif, 1993), 171-172. 


\section{E. Kedudukan Nuskhah Ali Bin Abi Tholhah}

Secara umum, nuskhah Abi Tholhah atau yang diriwayatkan oleh Mu'awiyah Bin Shalih memiliki kedudukan yang sangat penting. Demikian pentingnya Nuskhah tersebut, sehingga Imam Ahmad bin Hanbal menyatakan, bahwa di Mesir ada sebuah tulisan tafsir riwayat Ali bin Abi Tholhah, jika ada seseorang yang pergi ke Mesir, untuk tujuan mengambil nuskhah itu, maka hal itu akan membawa (kebaikan yang) banyak ${ }^{54}$. Imam Bukhari yang terkenal dengan kekuatan riwayatnya juga menggunakan tafsir dalam nuskhah Ali bin Abi Tholhah untuk menerangkan ayat-ayat yang berhubungan dengan istilah-istilah baru dalam al-Qur'an. Begitu juga Imam Mufassirin, Ibnu Jarir At-Thobari. Ibnu Jarir menampilkan hampir seluruh informasi tentang tafsir yang adalam teks milik Ali bin Abi Tholhah.

Lalu bagaimana dengan pendapat sebagian pakar hadits bahwa beliau meriwayatkan tafsir Ibnu Abbas namun belum bertemu dengan Ibnu Abbas? Untuk masalah ini, sebagian besar Ulama meyakini bahwa Ali bin Abi Tholhah mengambil teks yang ia riwayatkan melalui sahabat-sahabat Ibnu Abbas. Ada yang berpendapat bahwa salah satu sahabat tersebut adalah mujahid, ada pula yang berpendapat bahwa ia mengambil informasi tentang tafsir ini dari Sa'id bin Jabir, pendapat lain mengatakan bahwa ia mengambil tafsir tersebut dari Ikrimah mawla Abdullah Ibnu Abbas. ${ }^{55}$.

Sebagian besar Ulama terkemuka juga mengambil tafsir riwayat Ali bin Abi Tholhah karena mereka meyakini bahwa Ali bin Abi Tholhah mengambil tafsir tersebut dari orang-orang terpercaya (ats-tsiqat) yang sempat belajar kepada Abdullah Ibnu Abbas. Dalam hal ini, Imam Hadits Al-Hafizh Ibnu Hajar AlAsqolani berkata, "Dan Ali ia bisa dipercaya, dan ia belum bertemu Ibnu Abbas. Tetapi dia mengambil informasi dari orangorang terpercaya dari Para Sahabat Ibnu Abbas. Karena ini Imam Bukhari, dan Ibnu Abi Hatim, dan yang lainnya menggunakan nuskhah ini ${ }^{56}$ ". Sedangkan Jalaluddin As-Suyuti, ia berkata, "Dan setelah aku mengetahu perantaranya, dan mereka adalah orangorang terpercaya, maka tidak ada permasalahan dalam hal itu".

${ }^{54}$ Jalaluddin As-Suyuti, al-Itqan fi Ulum al-Qur'an, Jilid 4 (Majma' Malik Fahd, $1426 \mathrm{H})$.

55 Jalaluddin As-Suyuti, al-Itqan fi Ulum al-Qur'an, Jilid 4 (Majma' Malik Fahd, 1426 H), 207.

${ }^{56}$ Ibnu Hajar Al-Asqolany, al-Ujjab fi Bayani al-Asbab (Dar Ibnu Hazm, 2002), Jilid 1, 207. 
Demikianlah. Bahwa Ali bin Abi Tholhah memang tidak bertemu langsung dengan Abdullah bin Abbas, namun ia bertemu dengan murid Ibnu Abbas yang terkenal dan bisa dipercaya. Sehingga tafsir yang ia riwayatkan memiliki kedudukan yang sangat penting menurut Para Ulama Tafsir.

Lalu bagaimana dengan perawi yang meriwayatkan dari Ali bin Abi Tholhah? Mari kita lihat dua orang lainnya yang meriwayatkan nuskhah ini, yaitu:

1) Orang kedua dalam nuskhah ini ialah Muawiyah bin Shalih Al-Hamsi, hakim di Andalusia, ia dianggap terpercaya oleh Ibnu Mahdi, Ahmad, Ibnu Mu'ayyan, Ibnu Sa'd, Abu Zar'ah, Abu Hatim, Al-Ajli, An-Nasa'i, Ibnu Ammar, Ibnu Adiy, Ibnu Hibban, Al-Bazzar, dan Imam Muslim juga menggunakan pendapatnya dalam kitab sahihnya.

2) Orang ketiga dalam nuskhah ini ialah Abdullah bin Shalih AlMasry, asisten (pencatat) Imam Al-Layts. Ia dianggap terpercaya oleh Para Ulama, antara lain Ibnu Mu'ayyan, Abu hatim Ar-Rozi, Abu Zar'ah, Abu Harun Al-Khoribi, Ya'qub bin Sufyan, Ibnu Adiy, Maslamah bin Qasim, Ibnu Qattan, An-Nasa'i, Ibnu Al-Madini, Ibnu Hibban, Abu Ahmad AlHakim, dan yang lainnya. Secara umum, ia dikenal sebagai orang yang bisa dipercaya hafalan dan tulisannya ${ }^{57}$.

Berdasarkan pembahasan di atas kita dapat melihat, bahwa jalur perawi antara Ali bin Abi Tholhah dan para Ulama setelahnya dianggap cukup kuat dan bisa dipercaya. Hal ini tentu saja memberikan nilai positif bagi nuskhah yang diriwayatkan oleh Ali bin Abi Tholhah tersebut.

Secara umum kita dapat menilai bahwa, nuskhah Ali bin Abi Tholhah memang dianggap sebagai salah satu jalur periwayatan terbaik dan paling shahih yang diambil dari Abdullah Ibnu Abbas. Karena itulah riwayatnya digunakan oleh Ulama-Ulama terkemuka, seperti Al-Bukhari, Ibnu Jarir, Ibnu Abi Hatim, dan Ibnu Al-Mundzir ${ }^{58}$.

${ }^{57}$ Jalaluddin As-Suyuti, al-Itqan fi Ulum al-Qur'an, Jilid 4 (Majma' Malik Fahd, 1426 H), 207.

58 Jalaluddin As-Suyuti, al-Itqan fi Ulum al-Qur'an, Jilid 4 (Majma' Malik Fahd, 1426 H), 207. 


\section{F. Teks Nuskhah Ali Bin Abi Tolhah}

Meskipun nuskhah ini dahulu terkumpul dalam satu kertas atau kumpulan kertas, namun nampaknya seiring berjalannya waktu, nuskhah tersebut tidak lagi tersimpan dan hilang. Maka dari itu, sebagian besar Ulama menelaah nuskhah ini melalui tulisan-tulisan Ahli Tafsir yang pernah membacanya, terutama Ibnu Jarir At-Thobari. Karena Tafsir At-Thobari dianggap telah menghimpun sebagian besar penafsiran Abdullah Ibnu Abbas. Karena itu, setelah penulis berusaha mencari teks asli nuskhah tersebut melalui internet ternyata tidak ada, yang ada adalah kumpulan tafsir Ibnu Abbas riwayat Ali bin Abi Tholhah yang dikumpulkan oleh Ahmad 'Aisy Al-Latif Al-'Ani tahun 1409H/1989M, dalam risalah magisternya di Universitas Ummul Qura Saudi Arabia.

Tafsir tersebut ia kumpulkan dari bebagai sumber, terutama dari Tafsir Ibnu Jarir At-Thobari ${ }^{59}$. Namun penulis hanya menemukan satu jilid dari risalah magister tersebut (diperkirakan risalah tersebut terdiri dari 2 jilid), sehingga penafsiran Ibnu Abbas yang terhimpun dalam risalah magister jilid 1 tersebut hanya dari surat al-Baqarah sampai surat alAn'am.

Selain dalam bentuk penelitian yang dilakukan oleh Ahmad 'Aisy Al-Latif Al-'Ani, ada pula kitab lain, yang berjudul "Tafsir Ibnu Abbas Al-Musamma Shahifatu Ali bin Abi Tholhah 'an Ibni Abbas", di-tahqiq oleh Rasyid Abdul Mun'im Ar-Rijal. Kitab ini diterbitkan oleh Muassah Al-Kutub Ats-Tsaqafiyah, Beirut. Secara umum kitab ini cukup lengkap menghimpun penafsiran Abdullah Ibnu Abbas. Selain itu terdapat pula penjelasan tentang kepribadian Ali bin Abi Tholhah, kisah hidupnya, dan penjelasan tentang sanad yang meriwayatkan penafsiran Abdullah Ibnu Abbas melalui jalur Ali bin Abi Tholhah. Untuk teks tafsirnya sendiri, penulis mendapati bahwa sebagian besar surat dalam Al-Qur'an. Surat-surat yang tidak ada teks penafsirannya ada 8 surat, antara lain $^{60}$ : Surat al-Fatihah, alLail, al-Alaq, al-Qodr, al-Bayyinah, al-Kafirun, an-Nasr, alMasad.

${ }^{59}$ Ahmad 'Aisy Al-Latif Al-'Ani, Shahifah Ali Bin Abi Tholhah 'An Ibni Abbas Radhiyallah 'Anhuma, (Saudi Arabia: Fakultas Ushuluddin Program Studi Kitab Wa Sunnah. Universitas Ummul Qura, 1989), 20.

60 A-Rijal, Rosyid Abdul Mun'im, Tafsir Ibnu Abbas al-Musamma Shahifatu Ali Bin Abi Tholhah 'An Ibni Abbas, cet.1 (Beirut: Muassah AlKutub Ats-Tsaqafiyah, 1991). 
Sedangkan sisanya, yaitu 106 surat, penulis menemukan penafsirannya dalam kitab tersebut, meskipun tidak semua ayat ada penafsirannya.

Jika kita melihat fakta di atas, maka kita dapat mengambil kesimpulan, bahwa tidak semua ayat al-Qur'an ditafsirkan oleh Abdullah Ibnu Abbas. Penyebab hal ini kemungkinan, karena pada saat al-Qur'an turun, Bahasa Arab Umat Islam yang membaca al-Qur'an masih cukup baik. Dan sebagian besar ayatayat al-Qur'an masih dapat dipahami dengan baik. Maka dari itu, kita mendapati bahwa penafsiran Abdullah Ibnu Abbas difokuskan kepada kata-kata yang sulit, dan ayat-ayat yang butuh penafsiran. Maka tidak semua ayat ditafsirkan oleh Abdullah bin Abbas. Meskipun begitu, kita dapat melihat bahwa penafsiran Abdullah Ibnu Abbas cukup lengkap, mencakup hampir seluruh surat yang ada dalam al-Qur'an. Maka tidak heran jika Para Ulama menjuluki beliau sebagai "Penerjemah al-Qur'an" atau Turjuman al-Qur'an.

\section{G. Tanwir Al-Miqbas Min Tafsir Abdullah Ibnu Abbas}

Ada satu buku lagi yang dapat kita temukan tentang Tafsir Abdullah Ibnu Abbas, yaitu tafsir yang dikumpulkan oleh Abu thohir Muhammad bin Ya'qub Al-Fairuz Abadi As-Syafi'i, penulis kamus Al-Muhith. Ia mengumpulkan tafsir yang diberi judul "Tanwir Al-Miqbas min Tafsir Ibni Abbas"61. Tafsir ini sangat lengkap, dari Surat Al-Fatihah hingga Surat an-Nas. Dan mencakup semua ayat dalam surat-surat tersebut. Tentu saja kitab tafsir ini menjadi sangat menarik karena ditulis dengan membawa nama Abdullah Ibnu Abbas. Namun terdapat catatan yang kurang baik dari para pengamat tentang tafsir ini, terutama berkaitan dengan sanad perawinya yang dianggap kurang terpercaya.

Jika kita baca di bagian awal dari tafsir tersebut, kita akan melihat nama-nama perawi tafsir tersebut, sanad yang dicantumkan dalam tafsir tersebut didapatkan melalui jalur Muhammad bin Marwan as-Suddi as-Shaghir, dari Muhammad bin As-Saib Al-Kalbi, dari Abu Shalih, dari Ibnu Abbas. Dan telah kita bahas sebelumnya, bahwa jalur Al-Kalbi dari Abi Shalih dari Ibnu Abbas merupakan jalur yang paling lemah menurut para Ulama ${ }^{62}$.

${ }^{61}$ Diterbitkan Oleh Darul Anwa al-Muhammadiyah, Kairo.

${ }^{62}$ Ahmad 'Aisy Al-Latif Al-'Ani, Shahifah Ali Bin Abi Tholhah 'An Ibni Abbas Radhiyallah 'Anhuma, (Fakultas Ushuluddin Program Studi Kitab Wa Sunnah: Universitas Ummul Qura Saudi Arabia, 1989), 55. 
Maka kita dapat mengambil kesimpulan bahwa tafsir yang dinisbahkan kepada Abdullah bin Abbas ini tidak shahih, dikarenakan lemahnya para perawi. Ditambah lagi, terdapat perbedaan antara riwayat yang dimuat di dalam tafsir al-Miqbas, dan riwayat yang dimuat di dalam shahifah yang diriwayatkan oleh para perawi yang bisa dipercaya, terutama dalam shahifah Ali bin Abi Tholhah. Meskipun begitu, tentu saja tafsir al-Miqbas tetap merupakan kitab tafsir yang bernilai tinggi, yang perlu diteliti adalah sumbernya, yang diyakini oleh para pakar, bahwa tafsir tersebut bukan dari Abdullah bin Abbas. ${ }^{63}$

\section{H. Ciri Penafsiran Abdullah Ibnu Abbas}

Secara umum, dalam pembahasa tentang corak penafsiran Abdullah bin Abbas dalam shahifah Ali bin Abi Tholhah, penulis menemukan bahwa Abdullah bin Abbas menggunakan empat cara:

1) Tafsir al-Qur'an dengan al-Qur'an

Tafsir jenis ini banyak digunakan oleh para Ulama sebagaimana juga digunakan oleh Para Sahabat, termasuk Abdullah bin Abbas. Karena al-Qur'an memang Allah turunkan sebagai penjelasan untuk segala sesuatu, termasuk penjelasan rinci hal-hal yang penting. Sebagaimana Allah Swt berfirman:

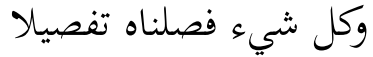

Artinya: Dan segala sesuatu kami jelaskan dengan perinciannya. (QS. al-Isra': 12).

Bahkan Ibnu Taimiah ${ }^{64}$ dan Al-Hafizh Ibnu Katsir menyatakan, bahwa tafsir al-Qur'an dengan al-Qur'an merupakan cara terbaik dalam menafsirkan al-Qur'an. Karena Ayat al-Qur'an ada yang turun secara umum di suatu surat, dan ia turun juga di surat yang lain dengan lebih rinci. Sebagian ayat al-Qur'an ada yang ringkas, dan ada pula yang panjang. Sebagian ayat ada yang umum, ada pula yang khusus.

${ }^{63}$ Ahmad 'Aisy Al-Latif Al-'Ani, Shahifah Ali Bin Abi Tholhah 'An Ibni Abbas Radhiyallah 'Anhuma (Fakultas Ushuluddin Program Studi Kitab Wa Sunnah: Universitas Ummul Qura Saudi Arabia, 1989), 55.

${ }^{64}$ Muqaddimah Ushul Tafsir, Tahqiq Adnan Zarzur, cet.1 (Kuwait Darul Qur'an Al-Karim, tt), 93 
Ada yang terbuka (muthlaq), ada pula yang terikat (muqayyad). Sehingga sebagian ayat al-Qur'an dapat menafsirkan sebagian yang lain ${ }^{65}$.

Abdullah bin Abbas menggukan metode ini dalam banyak ayat. Salah satunya saat menafsirkan ayat:

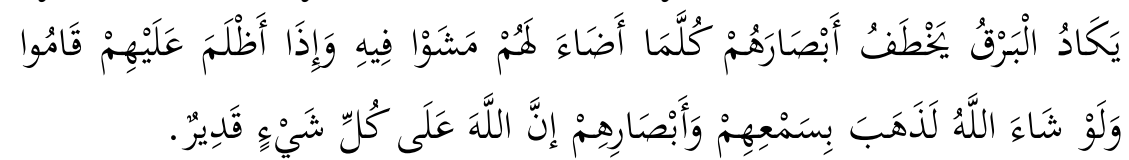

Artinya: "Hampir-hampir petir manyambar penglihatan mereka, setiap petir tersebut menerangi mereka, mereka berjalan, dan saat mereka dalam kegelapan mereka berdiri dan berhenti. Dan jika Allah mengehendaki Dia dapat menghilangkan pendengaran dan penglihatan mereka, dan Allah Maha Kuasa atas segala sesuatu”. (QS. al-Baqarah: 20)

Abdullah bin Abbas berkata, bahwa saat kemuliaan islam mengenai diri mereka, mereka merasa tenang, dan jika islam terkena noda atau terkena nuktah, mereka bangkit dan kembali kepada kekafiran. Sebagaimana firman Allah Swt:

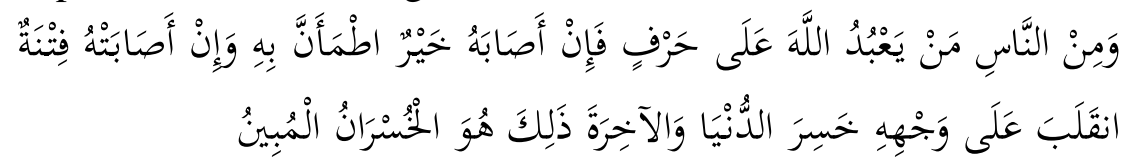

Artinya: "Dan sebagian manusia ada yang menyembah Allah dengan satu cara, maka ketika ia terkena kebaikan ia merasa tenang, dan saat ia terkena cobaan, ia kembali membalikkan wajahnya, ia rugi dunia dan akhirat, itulah kerugian yang nyata". (QS. al-Haj: 11).

Pada ayat yang lain, dalam menafsirkan dua ayat berikut:

$$
\text { وَالََْْضَ بَعْدَ ذَلِكَ دَحَاهَا (النازعات }
$$

Artinya: "Dan Bumi setelah itu Dia hamparkan".

${ }^{65}$ Abu Bakr Kafi, "Nusakh Haditsiyah Al-Manqulah 'An Shahabah Fi At-Tafsir Ta'rifuha-Ahammiyatuha-Qimatuha Nuskhah Ali Bin Abi Thalhah Namudzajan”, Majalah Al-Mi'yar. Edisi 44. Jilid 22, 2018, 102-109. 


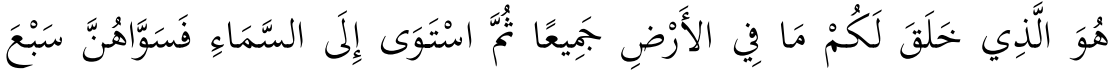

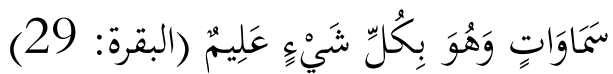

Artinya: "Dia yang menciptakan untuk kalian apa-apa yang ada di Bumi seluruhnya, kemudian ia bersemayam menuju langit, maka Dia menyamakannya menjadi tujuh langit. Dan Dia Maha Mengetahui segala sesuatu. (QS. al-Baqarah: 29).

Abdullah bin Abbas menyebutkan bahwa pada surat alBaqarah ayat 29 Bumi disebutkan sebelum langit, kemudian di surat An-Nazi'at ayat 30, langit disebutkan sebelum bumi. Mengapa demikian? Hal ini karena Allah Swt menciptakan Bumi dengan segala macam makanannya, tanpa menghamparkannya. Kemudian Allah Swt bersemayam di langit, dan menyamakan komposisinya menjadi tujuh langit, barulah kemudian Allah Swt menghamparkan Bumi. Maka dari itu Allah Swt berfirman, "Dan Bumi setelah itu Dia hamparkan" (QS. an-Nazi'at: 30). Ini adalah sebagian contoh, dan masih banyak lagi contoh-contoh lainnya, karena Abdullah bin Abbas banyak menggunakan metode ini dalam tafsirnya ${ }^{66}$.

2) Tafsir al-Qur'an dengan as-Sunnah

Metode lain yang digunakan oleh Abdullah bin Abbas ialah menggunakan Hadits Nabi untuk menafsirkan sebagian Ayat. Salah satunya yang disebutkan dalam tafsirnya, ialah firman Allah Swt:

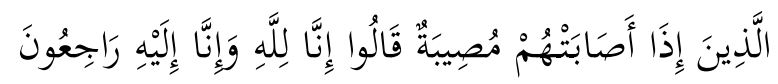

Artinya: "Orang-orang yang saat ditimpa musibah, mereka berkata: Sesungguhnya Aku milik Allah, dan sesungguhnya kepadaNya aku akan kembali”. (QS. al-Baqarah: 156).

${ }^{66}$ Abu Bakr Kafi, "Nusakh Haditsiyah Al-Manqulah 'An Shahabah Fi At-Tafsir Ta'rifuha-Ahammiyatuha-Qimatuha Nuskhah Ali Bin Abi Thalhah Namudzajan”, Majalah Al-Mi'yar. Edisi 44. Jilid 22, 2018, 102-109. 
Ibnu Abbas berkata: "Allah Swt mengabarkan bahwa seorang yang beriman, jika ia menyerahkan utusan kepada Allah Swt, dan kemudian kembali kepada Allah, dan membaca lafaz istirja' (Inna lillahi wa inna ilihi rojiun). Allah tuliskan bagi mereka tiga kebaikan: sholawat dari Allah, rahmat, dan penguatan di jalan kebenaran. dan Rasulullah Saw brsabda: 'barang siapa membaca istirja' saat terkena musibah, Allah akan memudahkan musibahnya, dan memperbaiki ujungnya, dan menjadikan untuknya penerus yang shaleh yang diridhoinya" $"$.

3) Tafsir al-Qur'an dengan Lisan Orang Arab

Al-Qur'an turun dalam Bahasa Arab, dan sebagian penafsiran berujung pada permasalahan Bahasa. Ibnu Abbas adalah sosok yang senang membaca dan memiliki pemahaman yang baik dalam Bahasa Arab. Dalam hal ini, dalam sebuah riwayat Abdullah bin Abbas berkata, "Syi'ir adalah diwan (kantornya) Bangsa Arab, maka jika ada sesuatu yang tersembunyi dari al-Qur'an yang diturunkan dalam Bahasa Arab, maka kita seharusnya kembali kepada diwan (kantor) mereka. Maka kita akan menemukan sebagian informasi tentang hal tersebut" $" 68$.

Menurut Ibnu Abbas, tafsir jenis ini merupakan tafsir yang bisa digunakan. Dan ini merupakan salah satu bentuk utama tafsir al-Qur'an menurut Ibnu Abbas, sebagaimana ia berkata: "Tafsir itu empat bentuknya: Tafsir yang dipahami Bangsa Arab dari perkataan mereka, tafsir yang tidak seorang pun beralasan bahwa ia tidak mengetahuinya, tafsir yang dipahami Ulama melalui ilmu mereka, dan tafsir yang tidak diketahui kecuali oleh Allah" $" 69$.

Ibnu Abbas menggunakan penafsiran ini di banyak tempat. Antara lain, Ibnu Abbas menafsirkan lafaz "يؤمنون" dengan

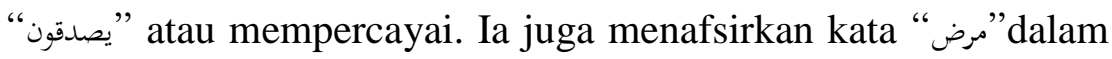

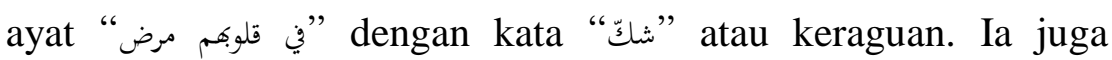
menafsirkan lafaz "يعمهون" dengan lafaz "يتمادون", kemudian ia

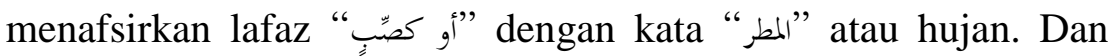
banyak lagi penafsiran lainnya ${ }^{70}$.

${ }^{67}$ At-Thobari, Jami' al-Bayan, Jilid 3, 223.

${ }^{68}$ Jalaluddin As-Suyuti, al-Itqan fi Ulum al-Qur'an, Jilid 2, 55.

${ }^{69}$ Ibnu Katsir, Muqaddimah Tafsir al-Qur'an al- 'Azhim, Jilid 1, 23.

${ }^{70}$ Abu Bakr Kafi, "Nusakh Haditsiyah Al-Manqulah 'An Shahabah Fi At-Tafsir Ta'rifuha-Ahammiyatuha-Qimatuha Nuskhah Ali Bin Abi Thalhah Namudzajan, Majalah Al-Mi'yar. Edisi 44. Jilid 22, 2018,102-109. 
Itulah tadi sebagian dari metode-metode utama yang digunakan oleh Abdullah bin Abbas dalam tafsirnya. Dalam hal isi tafsir, Abu Bakr Kafi merinci, bahwa tafsir Ibnu Abbas mengandung hal-hal penting yang juga terkandung buku-buku tafsir lainnya, seperti ${ }^{71}$ :

1) Asbab Nuzul

2) Makki Madani

3) Nasikh dan mansukh

4) Hukum-hukum fiqih

5) Penjelasan kisah-kisah al-Qur'an

6) Penjelasan makna-makna yang dimaksud oleh al-Qur'an

7) Penjelasan perumpamaan-perumpamaan dalam al-Qur'an

Berdasarkan penjabaran di atas, kita dapat melihat bahwa penafsiran Abdullah bin Abbas mencakup hampir semua permasalahan dalam tafsir al-Qur'an, termasuk sebagian permasalahan penting dalam kajian Ulum al-Qur'an. Sebagaimana Ibnu Abbas juga menafsirkan sebagian besar isi alQur'an, sedangkan sebagian yang lain tidak dijelaskan oleh beliau, karena dianggap sebagai ayat-ayat yang penafsiran dapat dilakukan oleh semua orang.

${ }^{71}$ Abu Bakr Kafi, "Nusakh Haditsiyah Al-Manqulah 'An Shahabah Fi At-Tafsir Ta'rifuha-Ahammiyatuha-Qimatuha Nuskhah Ali Bin Abi Thalhah Namudzajan", Majalah Al-Mi'yar, Edisi. 44, Jilid. 22, 2018, 102-109. 


\section{Penutup}

Dalam artikel ini, kita dapat mengambil simpulan, bahwa Abdullah bin Abbas merupakan salah satu Sahabat Nabi Muhammad Saw yang paling banyak menafsirkan ayat-ayat alQur'an. Beliau juga memiliki jasa yang besar dalam meriwayatkan hadits-hadits Rasulullah Saw, bahkan beliau menempati urutan keempat paling banyak dalam periwayatan hadits. Hal ini karena kecintaannya kepada ilmu pengetahuan, dan konsistensinya dalam berguru dan menemani Rasulullah Saw ke mana pun beliau pergi. Sehingga Ibnu Abbas diakui oleh para Sahabat dan para Ulama sebagai salah satu sosok yang paling alim dalam ilmu al-Qur'an, sehingga dijuluki sebagai "Turjuman al-Qur'an" atau "Penerjemah al-Qur'an". Banyaknya murid beliau juga membuat tafsir beliau beredar luas di kalangan ulama, sehingga sebagian riwayat tafsir tersebut masih bisa kita akses sampai sekarang.

Penulis mendapati, bahwa nuskhah atau shahifah Ali bin Abi Tholhah merupakan teks yang sangat berharga bagi Umat Islam karena merupakan salah satu teks paling orisinil yang mengandung tafsir Abdullah bin Abbas nuskhah tersebut memiliki sanad yang bisa dipercaya oleh sebagian besar ahli hadits, meskipun terdapat ketidak percayaan dari sebagian pakar hadits, karena Ali bin Abi Tholhah dianggap memiliki mazhab yang keras terhadap orang-orang dan pemimpin yang berbuat keburukan.

Tafsir Ibnu Abbas secara umum memiliki karakter yang mirip dengan tafsir-tafsir modern. Dalam tafsirnya, Ibnu Abbas menggunakan penafsiran dengan al-Qur'an, penafsiran dengan sunnah Nabi Muhammad Saw, dan juga penafsiran dengan menggunakan kosa kata Bahasa Arab. Tafsir Ibnu Abbas juga mengandung berbagai pembahasan penting, seperti: kata-kata sulit (al-gharib), Asbab Nuzul, Makki Madani, Nasikh dan Mansukh, Hukum-hukum fiqih, penjelasan kisah-kisah al-Qur'an, penjelasan makna-makna ayat, serta penjelasan perumpamaanperumpamaan dalam al-Qur'an. 


\section{Daftar Pustaka}

Abdullah, A, "Metodologi Penelitian, Corak dan Pendekatan Tafsir Al Qur'an. Journal al-Manar, 6(1), 2017.

Aberbach, David. "Introduction", In The Bible And The'holy Poor', Pp. 9-21. Routledge, 2017.

Abu Bakr Kafi, "Nusakh Haditsiyah Al-Manqulah 'An Shahabah Fi At-Tafsir Ta'rifuha-Ahammiyatuha-Qimatuha Nuskhah Ali Bin Abi Thalhah Namudzajan, Majalah AlMi'yar. Edisi 44. Jilid 22, 2018.

Al-'Ani, Ahmad 'Aisy Al-Latif, Shahifah Ali Bin Abi Tholhah 'An Ibni Abbas Radhiyallah 'Anhuma. Fakultas Ushuluddin Program Studi Kitab Wa Sunnah. Universitas Ummul Qura Saudi Arabia, 1989.

Al-Andalusi, Abdul Malik Bin Habib Abi Marwan As-Sulmi, Kitab Al-Mihbar. Jam'iyyat Dairotul Ma'arif AlUtsmaniyah, $1361 \mathrm{H}$.

Al-Asqolani, Ahmad Bin Ali Bin Muhammad Bin Ahmad Bin Hajar, Al-Ishobah Fi Tamyizi As-Shahabah. Jilid 2.

Al-Bar, Ibnu Abdi, Yusuf Abdullah Muhammad, Al-Isti'ab Fi Ma'rifati Shahabah. Tahqiq Muhammad Ali AlBukhari. Jilid 3, 1992.

Ali, Salim Abdu, Abdullah Bin Abbas Dirasat Fi Siratihi Wa Daurihi, Adab Ar-Rafidin. Edisi 65, 2013.

Al-Qattan, Khalil Manna', Mabahits Fi Ulum Al-Qur'an. Islamic Books, 2000.

Al-Ujjab Fi Bayani Al-Asbab, Jilid 1.

Aribowo, E. K, "Aspek-Aspek Linguistis Penanda Identitas Religi: Selayang Pandang Masyarakat Tutur Jawa Muslim", In Seminar Nasional dan Launching Adobsi. Surakarta: Asosiasi Dosen Bahasa dan Sastra Indonesia (adobsi), 2015.

Arifin, M. Z., Handayani, D., Phantawi, S., \& Nipapan, N, "Studi Living Qur'an: Pembacaan Ayat-Ayat Al-Qur'an dalam Prosesi Isi Qubur di Kota Bangkok Thailand, Realita, 14(1), 2016.

A-Rijal, Rosyid Abdul Mun'im, Tafsir Ibnu Abbas Al-Musamma Shahifatu Ali Bin Abi Tholhah 'An Ibni Abbas, cet.1, Muassah Al-Kutub Ats-Tsaqafiyah. Beirut, 1991.

As-Suyuti, Jalaluddin, al-Itqan fi Ulum al-Qur'an, Majma' Malik Fahd. Jilid 4, 1426 H. 
Atabik, A, "Perkembangan Tafsir Modern di Indonesia, Dalam Jurnal Hermeunetik, 8(2), 2014.

At-Thobari, Jami' Al-Bayan. Jilid 3.

Azis, S. I. A, Pandangan Bintu Syathi Tentang Qasam: Studi Kitab Al-Tafsir Al-Bayani Lil Qur'an Al-Karim, Doctoral Dissertation, UIN Raden Intan Lampung, 2018. Az-Zahabi, Siyar A'lam Nubala, Baitul Afkar Al-Waliyyah. Tahqiq Hassan Abdul Mannan, Jilid 3, 2009.

Bahruddin, A. H., Mujahidin, E., \& Hafidhuddin, D, "Metode Tahfizh Al-Quran Untuk Anak-Anak Pada Pesantren Yanbu'ul Qur'an Kudus Jawa Tengah", Ta'dibuna, 6(2), 2018.

Cantoni, D, "The Economic Effects Of The Protestant Reformation: Testing The Weber Hypothesis In The German Lands", Journal Of The European Economic Association, 13(4), 2015.

Gharro, R, Pakaian dalam Al-Qur'an Perspektif Zamakhsyari dalam Tafsir Al Kasyaf: Telaah Penafsiran Kata Libas, Thiyab Dan Sarabil, Doctoral Dissertation, Uin Sunan Ampel Surabaya, 2018.

Hanafi, A. H, Lembaga Pendidikan Tinggi Islam: Harapan, Tantangan, Paradigma, Dan Peranan Bahasa Arab. AlFikrah: Jurnal Manajemen Pendidikan, 1(1), 2016.

Karahan, Harun Dündar, "Understanding of Revelation In Christian Sects." Bozok University Journal of Faculty Of Theology [Bozifder] 13, No. 13, 2018.

Munir, A, “Konsep Dasar Pendidikan Dalam Al-Qur'an”, Kreatif: Jurnal Studi Pemikiran Pendidikan Agama Islam, 13(2), 2015.

Muttaqin, T, "Khazanah Ulama Nusantara: Tafsir Murāh Labīd Karya Nawawi Banten", Al-A'raf: Jurnal Pemikiran Islam Dan Filsafat, 12(2), 2015.

Nasution, A. H., \& Mansur, M, 'Studi Kitab Tafsīr Al-Qur’ān AlAzim Karya Ibnu Kasir, Jurnal Ushuluddin Adab Dan Dakwah, 1(1), 2018.

Nasution, H. S, "Epistemologi Question: Hubungan Antara Akal, Penginderaan, Intuisi dan Wahyu dalam Bangunan Keilmuan Islam”, Almufida, 1(1), 2016.

Qutaybah, Ibnu, Kitabul Ma'arif, T.tp: tp, tt.

Rofah, Muhammad, "Musahamah Ulama al-Maghrib al-Ausath al-Hadhoriyah Min Khilal Tafsir As-Syaikh Hud Bin Muhkam Al-Hawari”, At-Ta'limiyah. 6(1), 2018. 
Sa'd, Ibnu, at-Thobaqat al-Kubro, Maktabatul Khanji, Jilid 2, 2001.

Saeed, A, Al-Qur'an Abad 21: Tafsir Kontekstual, Terj. Ervan Nurtawab, Bandung: Mizan, 2016.

Sarumaha, N, "Eskatologi Dalam Injil Markus", Epigraphe: Jurnal Teologi Dan Pelayanan Kristiani, 1(2), 2018.

Siahaan, D. S, "Ketika Aku dan Kamu Menjadi Kita: Dialog Misi Penginjilan Kristen dengan Dakwah Islam Menggunakan Pendekatan Teologi Interkultural dalam Konteks Indonesia", Gema Teologika, 2(1), 2017.

Sinukaban, E. A, Prinsip Hidup Jemaat Mula-Mula dalam Kisah Para Rasul, 2018.

Sobki, I. M., Yusof, N., \& Yusof, Y, Qira'at Reading As Sunnah Muttaba'ah: A Perspective Study On Orientalist Views. International Journal Of Academic Research In Business And Social Sciences, 2017.

Taufik, M. H. N., Isnaini, N., \& Khumairoh, R, Urgensi Keluarga Dalam Masyarakat Arab. Semnasbama, 2018.

Wekke, I. S., Tamimi, R. H., \& Sugandi, B, Muhammad Saw Dan Peletakan Dasar Peradaban Islam. Aqlam: Journal Of Islam And Plurality, 3(1), 2018.

Zainuddin, A. Z. A, Tafsir Bi Al Ra'yi. Mafhum, 1(1), 2017.

Zarzur, Adnan, Muqaddimah Ushul Tafsir, Tahqiq Adnan Zarzur, cet.1, Kuwait: Darul Qur'an al-Karim, tt.

Zayd, Bakr Abu, Ma'rifatu An-Nusakh dan Shuhuf Haditsah, Daru ar-Royah, 1992. 